\title{
PROCEEDINGS PAPERS
}

\author{
Winter Meeting of the American Farm Economic \\ Association with Allied Social \\ Science Associations
}

Boston, December 27-29, 1963

\section{THE POVERTY PROBLEM IN AMERICAN AGRICULTURE}

Chatrman: Stanley K. Seaver, University of Connecticut

\section{Relevant Alternatives in Resolving the Rural Poverty Problem}

\author{
LEE R. MARTIN
}

IT

HE PURPOSE here is to list and examine briefly those alternatives that might be created by the land-grant system (including the USDA and the land-grant universities), or by other institutions with similar competences, interests, and resources. The means would be the traditional methods developed by that system-the creation, assembly, and dissemination of relevant information. It is not that other groups have no role to play but that knowledge is basic to any actions likely to lead to a reduction in rural poverty. It is assumed that rural areas would be willing to take political as well as economic actions, and in the public as well as in the private sector.

Two general types of solutions suggest themselves. One is to take existing growth rates in national income and employment to be the best attainable and to redistribute income in favor of households with low levels of purchasing power. ${ }^{1}$

The second general type of solution would be to increase the total

${ }^{1}$ In an economy with unemployed or underemployed human resources and underutilized production capacity, redistributing purchasing power toward households with higher marginal propensities to consume would increase GNP slightly.

LEE R. MARTIN is visiting professor of resource economics at the University of Michigan. 
volume of human resource utilization in the economy, on the assumption that rural residents would qualify for some of the additional jobs. Bishop's prize-winning article [4] reported little reluctance among rural people to take advantage of bona fide employment opportunities, even if the change meant moving long distances.

Midway between these solutions is to increase the number of gainfully employed without increasing total hours worked; this involves shortening the work week, extending the length of vacations, and so on. The unemployed would give up leisure for income, the underemployed would give up somewhat less leisure for additional income, while the fully employed would gain leisure at the expense of income. Such a redistribution of income and leisure presumes that no feasible means can be found to increase effective demand enough to sustain a larger volume of employment (in total hours worked). This mixed solution needs to be examined carefully. While the economic welfare of the erstwhile unemployed and underemployed would be increased, it seems certain that welfare of the fully employed would be diminished as a result of reducing their total income and hours worked. A net increase in the number of gainfully employed, in the total utilization of human resources, and in the GNP would be more likely to increase total economic welfare. This leaves two questions needing answers. First, is a substantial increase in employment feasible? Second, are there actions that rural people or their leaders might take that would lead to increased employment and income?

\section{Magnitude of the Need for Additional Employment}

No precise estimate of the unemployed and underemployed labor force -urban and rural-is possible because the size of the labor force results from an aggregate of individual reactions to an environment (of plentiful jobs) that has not existed since the Korean War. Nevertheless, conservative estimates of total unemployment and underemployment are available for a recent year. Bachmura [1] has presented rough estimates for 1960 . Table 1 shows that approximately 6.7 million additional jobs would have been needed in 1960 to employ 100 percent of the civilian labor force. Four million were reported in conventional unemployment, nearly 2.7 million were the estimated unemployment equivalent of the rural underemployed, 1.1 million in agriculture and 1.6 million outside agriculture. With 31 percent of the 1960 population, the South had 36 percent of the total unemployment; with only 22 percent of the conventional unemployment, that region had over 56 percent of the rural underemployment. The last column in Table 1 shows by regions the percentage total unemployment was of nonfarm employment in 1960. The percentage for the country was 12.7, and the range was from 9.1 percent in the East 
North Central region and 10.2 in New England to 13.7 in the West North Central region and 16.9 percent in the South.

Table 1. Estimates of unemployment and underemployment, 1960, by regions

\begin{tabular}{|c|c|c|c|c|c|}
\hline \multirow{2}{*}{ Region } & \multirow{2}{*}{$\begin{array}{c}\text { Conven- } \\
\text { tional } \\
\text { reported } \\
\text { unemploy- } \\
\text { ment }^{\mathrm{a}}\end{array}$} & \multicolumn{2}{|c|}{$\begin{array}{l}\text { Estimated unemploy- } \\
\text { ment of equivalent } \\
\text { rural persons }\end{array}$} & \multirow{2}{*}{$\begin{array}{l}\text { Total } \\
\text { unemploy- } \\
\text { ment }\end{array}$} & \multirow{2}{*}{$\begin{array}{l}\text { Percent of } \\
\text { nonfarm } \\
\text { employment }\end{array}$} \\
\hline & & $\begin{array}{c}\text { In } \\
\text { agriculture }\end{array}$ & $\begin{array}{c}\text { Outside } \\
\text { agriculture }\end{array}$ & & \\
\hline \multicolumn{6}{|c|}{ (Thousands) } \\
\hline New England & 300 & 11 & 64 & 375 & 10.2 \\
\hline Middle Atlantic & 1,143 & 35 & 142 & 1,320 & 11.1 \\
\hline East North Central & 717 & 114 & 204 & 1,035 & 9.1 \\
\hline West North Central & 224 & 179 & 165 & 568 & 13.7 \\
\hline Mountain & 115 & 31 & 55 & 201 & 10.8 \\
\hline Pacific & 622 & 38 & 112 & 772 & 12.3 \\
\hline South & 886 & 652 & 850 & 2,388 & 16.9 \\
\hline South Atlantic & 416 & - & - & - & - \\
\hline East South Central & 223 & - & - & - & - \\
\hline West South Central & 247 & - & - & - & - \\
\hline United States ${ }^{\mathrm{C}}$ & 4,007 & 1,060 & 1,592 & 6,679 & 12.7 \\
\hline
\end{tabular}

- All residential sectors, rural and urban reported; allocation of national total based on average weekly state insured unemployment, 1962.

b Based on the $\$ 1,200$ criterion: estimated number of family heads, family members and unrelated individuals, with net annual income less than $\$ 1,200$. If the criterion is raised to $\$ 3,000$, the number of underemployed "family and household heads engaged in farming" goes from 726 to 1,853 thousand.

- Fifty states and the District of Columbia.

Source: Frank T. Bachmura, Agricultural Unemployment and Underemployment and Government Program Approaches, ERS, USDA, Washington, D. C., March 26-28, 1963, pp. 14, 16-17.

It should be emphasized that no modern industrial economy has been able to employ 100 perecnt of its civilian labor force for an extended period. If factor mobility could be increased by social action, unemployment might be held around 2 percent of the civilian labor force [8]. In 1960 , this minimum would have been 1.4 million workers out of a labor force of 70.6 million. Thus the additional employment needed in 1960 was 5.3 million, or almost exactly 10 percent of nonfarm employment.

The dynamic aspects of the problem may be seen by noting that the net 1960-1970 contribution of rural areas to the civilian labor force will be approximately five million. Also, employment in farming is expected to decline by one million during the decade, making six million additional jobs needed in the nonfarm sector during the 1960's for new entrants to the labor force from rural areas.

What would have been necessary in 1960 for 5.3 million more workers to be employed? For earned incomes to be adequate for a satisfactory living standard, a certain volume of producer capital would have been 
required. In 1962, investment per worker in agriculture was estimated at $\$ 23,300$ [3], per employee in industry at $\$ 17,500$ [6]. ${ }^{2}$ If we assume unrealistically that there was no unutilized or underutilized (private or public) producer capital in the economy, we might estimate that each additional worker would require capital at the same level as was available in each economic activity. A conservative estimate of $\$ 15,000$ per worker would mean a total of $\$ 79.5$ billion in additional producer capital to reduce unemployment by 5.3 million. This ignores the multiplier effect. There was in 1960 and is in 1964 (especially in the private sector) a considerable volume of underutilized producer capital. If this were sufficient for one-half of the new workers, the requirement would become something like $\$ 40$ billion. In the first 18 months, the ARA program made commitments of less than $\$ 50$ million for loans and grants, and for studies and surveys.

While provision of additional producer capital may be necessary for fuller employment, it is by no means sufficient. The urban unemployed and the rural underemployed are not well qualified for the new employment opportunities that arise today. Many unemployed and underemployed adult workers will need to be retrained to make them employable, and youngsters must have more schooling and training if their entry into the labor force is not to increase even more the already high unemployment rate for the 18-24 age group [7]. The growing importance of human capital is a direct result of the rapid technological change, and there is no evidence of a slackening in the need for education and training [5]. Whatever its exact magnitude there is certainly a substantial need for greater investment in human capital to enhance the potential productivity of human resources. Earlier this year it was reported that, under the Manpower and Training Act of 1962, 200 training projects affecting 23,000 people had been approved, with little enrollment of rural residents [2]. It seems safe to conclude in December 1963 that the inadequacy of programs to provide additional jobs is matched by those to form additional human capital.

\section{Options Available to Rural Communities and Regions}

The arguments to this point can be summarized in three statements. First, unemployment and underemployment problems among rural and urban residents are massive, appear to be growing, and are likely to grow more rapidly from 1965 on, when the flood of 18-year olds begins to enter the labor force. Second, barring unforeseen miracles, prospects are dim for the market mechanism unaided to generate large increases in the demand for human resources. Third, public programs designed to

2 In manufacturing the range was from $\$ 4,600$ in apparel to $\$ 56,000$ in petroleum and coal. 
create jobs and replace obsolete human skills are quite inadequate; these rest upon the curious philosophy that not a few but all impoverished communities can by herculean efforts raise themselves by their own bootstraps.

What can rural areas and regions do to increase their own economic welfare, other than try to take advantage of whatever market opportunities might develop, or seek subsidies from more affluent regions? By themselves, investments in producer capital are not enough; capitaldeepening investments are likely to raise the productivity of employed workers, but not to increase total employment opportunities. Capitalwidening investments would only add to the volume of underutilized capacity unless there should be a sudden and dramatic increase in the incremental capital-output ratio.

The great need is to increase nonfarm employment by something like 8 to 10 percent. How is this to be done? Because productive capacity is already excessive in relation to effective demand, a considerable increase in employment could be achieved by expanding effective demand. Except for the remote possibility of new products requiring large investments in producer capital long before any vendible output was forthcoming, other alternatives for increasing purchasing power require actions largely from the federal government.

Decisions to increase the budget deficit by increasing government spending or reducing tax revenues are made politically. More often than not Congressmen representing low income communities or regions oppose-on ideological grounds-any efforts to stimulate the economy through fiscal actions. These Congressmen are not unaware of the distressed areas in their districts; even the ultraconservatives are acutely aware. Seldom do Congressmen or local leaders associate the employment in low income areas with the level of economic activity. This seems generally to be the case in the South, in the Appalachian highlands, in the northern Great Lakes region, in northern New England, as well as in scattered pockets of rural poverty elsewhere in the nation.

To establish knowledge in low income communities of the connection between level of aggregate activity and local employment opportunities is within the competence of the land-grant system, with its capacities for research and for extension education [11]. This system can, if it chooses, work equally well at the grassroots or in Washington. The grassroots efforts will require additional research, to reveal more accurately and in more detail, the consequences of different combinations of policy variables. Research is badly needed to provide the Secretary of Agriculture and land-grant leaders with valid evidence of the stake rural families have in the performance of the total economy. The Departments of Labor and Commerce, and the Council of Economic Advisers have 
testified in Congress at length on the plight of the four million unemployed, and their stake in "getting the economy moving." Neither the USDA nor the land-grant universities (except scattered individuals) have dramatized the plight of the rural underemployed or even emphasized their stake in increased employment opportunities. There has been little effective concern in the Executive Branch or in Congress for the welfare of the rural labor force not needed in farming. The land-grant system has both the capacity and the resources to create, assemble, and disseminate the information required [11]; surely the welfare implications of doing so are obvious.

\section{Human Capital Needs of Rural Underemployed}

While creating millions of additional employment opportunities is necessary for alleviating chronic underemployment in rural areas, it is by no means a sufficient condition. Dramatic changes in the economy, based upon scientific and technological innovations, make education and training more and more necessary for workers to compete successfully for existing employment opportunities. There is a tendency for rural youth to obtain less schooling than their urban counterparts. Possibilities for vocational training are often much fewer in rural than in urban communities. Seldom are retraining opportunities available to rural adults. If the rural underemployed are to share in the additional employment with the urban unemployed, then substantial efforts will be needed to make sure they are fully qualified. One essential purpose for which employment-increasing purchasing power might be injected into the economy would be for additional education and training for youth and adults.

Equity would not be served by requiring low income communities to pay for educating and training the youth and for retraining adults with obsolete skills or none at all. The immediate benefits to a particular market area are likely to be too small to justify full costs; many trained individuals are likely to seek employment outside the market area, once they are qualified. The economy outside the low income area also needs to support these efforts, because of the benefits outside the area. More detailed information is needed on the social opportunity costs and benefits of investments in human capital, not only from the standpoint of society, but also regions, states, and market areas. Again, the land-grant system has the capacity and resources to create and disseminate this information.

\section{Location Theory and Low Income Areas}

Of all the information needed to guide areas in efforts to stimulate their own economic betterment, least satisfactory is that relating to the bases for the location of economic activities. Market areas on the make for jobs 
seldom have more than a rudimentary understanding of what can be done to enhance their qualifications. Systematic information is not available to help market areas determine what economic activities they might seek, what investments would be needed, and what investments would be justified. Conventional analyses of location tend to concentrate on input supply conditions and on the geographical aspects of product demand; on the human resource side, there is a tendency to count "warm bodies," leaving aside the major qualitative aspects of the labor force.

Better understanding of the aggregate production function for any economic unit larger than a firm might be achieved by dealing with broad classes of contributors to productive capacity. For example, potential national income in period $\mathbf{i}, \mathrm{Yi}=\mathbf{f}(\mathrm{Ni}, \mathrm{Xi} ; \mathrm{Zi} ; \mathrm{Ki} ; \mathrm{Wi} ; \mathrm{Ri})$, where $\mathrm{Ni}$ is the potential work force and $\mathrm{Xi}$ is the human capital embodied in it; $\mathrm{Zi}$ is available technology, $\mathrm{Ki}$ is private producer capital, $\mathrm{Wi}$ is community capital, and $\mathrm{Ri}$ is the natural resource base. At any point in time, one or more of these would constitute a limit to productive capacity, and would have to be increased to increase capacity. The volume of each can be increased by investments in education or training, research and development, producer capital, community capital, or in resource discovery.

For a proper economic unit (a market area, for example) productive capacity would be a function of these six variables. For any area or region, it should be possible to specify (for each of the 200 Leontief sectors of the economy, for example) what investments would be necessary to make a plant in that location competitive.

Substitutability as well as complementarity among these variables is significant for low income areas. Community capital (a free building) may be substituted for producer capital to enable a plant to be competitive. Resource investments may uncover resources whose existence or usefulness was previously unknown. Technology can be designed to increase the productivity of marginal resources. Shortages of human capital can be made up by education and training of local people, or by designing amenities (community capital) to attract talented individuals (research workers or managers) from other areas. The growing importance of human capital and technology increases the locational significance of fine universities, and of areas with excellent amenities. Human capital can be transformed into productivity-increasing technology.

As far as particular locations are concerned, locational analyses assume that private producer capital is not available, but will have to be put in place, whatever location is selected. Other forms of capital-human capital, technology, community capital, and natural resources-are not analyzed in the same way; the tendency is to search for economic activities to match the availability of these other capital forms. It is seldom considered that these can also be installed at a price. 
The extent to which the qualifications of a market area for a particular economic activity are affected by political decisions is not fully recognized. Taken together, federal, state, and local decisions almost completely determine these qualifications; deliberate attempts to improve them are almost entirely political. Government units participate in the financing of community capital, education and training, research and development, and resource discovery. Nonfiscal decisions by government agencies also influence the quality of the environment.

Techniques are not very well developed for determining what a market area could afford to spend in order to become a more efficient site for an economic activity. Estimates are possible of what the effects of additional employment would be on the market area and the state. Economists and regional scientists should be able to make useful approximations of the additions to employment, income, and tax revenues of local units. As a minimum effort, economic areas would appear to be justified in committing the expected increases in tax revenue, because the remainder of the increment to area income would provide for an increase in area welfare. A similar estimate could be made for the justifiable contribution of the state.

If these increments were not enough to enable the area to make the qualifying investments, then the tax system might be altered to make it yield more revenue. Another alternative coming into use by depressed areas is voluntary taxation, raising funds from area firms and plants that would benefit from the increase in area income. In a low income area, firms engaged in trade, services, construction, finance, real estate, communication, utilities, and transportation often operate below their capacity. Any increase in operating volume would be likely to increase net returns proportionately more than the increase in volume. These entrepreneurs could provide much of this additional income (net of income taxes) and still be better off than if there had been no expansion in income and employment.

Better analyses of the effects of economic expansion upon the revenues of a market area, of its business firms, and of the state are needed to improve estimates of the direct or indirect subsidies that could be justified. There is little doubt that carefully designed subsidies that provide the basis for economic expansion will improve economic welfare in a low income area [10].

One further aspect of location theory follows from the characteristics of a dynamic economy. From the viewpoint of any economic area, we can define economic activities as autonomous or dependent. If an activity produces goods or services sold largely to households or firms outside that area, then it is defined as autonomous. Increases in autonomous employment lead to increases in market size and to additional employment 
in dependent activities. Growth in an advanced economy emphasizes services more and goods relatively less.

To test the magnitude over time of these structural changes, I assumed major sectors to be composed of autonomous activities in the following percentages; agriculture and mining, 90; manufacturing, 80; finance, 70; transportation, 50; government, 40; services, 30 ; construction, 20; and trade, 10. Applying these assumptions to NPA estimates of employment [9] yielded the following ratios of dependent to autonomous employment: 1947, 0.92 dependent worker for each autonomous worker; $1957,1.04$ to $1 ; 1976,1.20$ to 1 ; and $2000,1.52$ to 1 . Under these assumptions, autonomous employment declines from 52 percent of the total in 1947 to less than 40 percent in 2000.

What this means is that a market area that can hold its autonomous employment constant from 1947 to 1957, 1976, and 2000 will make gains in dependent employment of 13 percent from 1947 to 1957, 24 percent from 1957 to 1976 , and 19 percent from 1976 to the year 2000; for the same periods the increases in total employment would be 6 percent, 12 percent and 10 percent, respectively. These averages for the whole economy indicate rough orders of magnitude for market areas.

Any market areas not satisfied with an annual employment growth rate of less than $1 / 2$ of 1 percent must develop means of increasing autonomous employment. This could come from the 1947-2000 increase in autonomous employment of 78 percent (against 194 percent in dependent employment), or from attracting autonomous activities away from present locations. Not only will competition become fiercer for the 23.4 million increase in autonomous employment estimated to take place between 1947 and 2000 , but intensive efforts will be required to keep from losing existing autonomous employment, estimated at 30.2 million in 1947.

While evidence is sketchy, indications are that government activities benefit economic growth efforts of large metropolitan areas more than smaller metropolitan areas, or than the smaller market areas interdependent with rural areas. Two types of government activities may be distinguished. First is the location of government activities; public employment is estimated to increase 245 percent from 1947 to 2000 . Seldom do rural and urban legislators and Congressmen combine their political strength to create any advantage for smaller centers. From 1800 to the 1920 's smaller centers competed effectively as locations for government activities. Despite the almost universal political overrepresentation of rural areas today, their representatives are outmaneuvered by their urban counterparts in locating public economic activities. The reason seems to lie in the attitudes of rural representatives, and in the fact that smaller market areas are not making enough progress in converting themselves into fully suitable locations for government activity. 
The second way in which federal and state governments have been more helpful to larger market areas is assistance in forming human and community capital, and in creating technology. Smaller centers have two disadvantages in building up their qualifications. One is that failure to appreciate the indispensability of human and community capital leads rural representatives to be indifferent while urban representatives design assistance programs that are more readily available to metropolitan areas. ${ }^{3}$ Second is that smaller centers are often driven by ideology not to take advantage of available assistance. Thus a great many smaller areas remain by conscious and unconscious choice unsuitable for any but the most marginal economic activities.

The writer's opinion is that rural areas could join with their dependent urban areas and operate politically to improve their growth prospects for many economic activities. Greater decentralization of economic activity need not entail significant losses in economic efficiency. Social efficiency would be increased by converting unemployment and underemployment into gainful employment by assisting the development of economic opportunities in urban centers near rural areas.

To sum up, rural areas need more reliable information than is now available, if they are to come to grips with their poverty problems. Included are:

1. determination of autonomous economic activities;

2. locational requirements of different economic activities;

3. investments needed to qualify as efficient locations for particular economic activities;

4. investments that would be justified to become efficient locations;

5. possibilities for using research to create technology to increase the productivity of human, natural, and man-made resources in rural areas;

6. possible improvements in the environment that could be accomplished through political action at the federal, state, or local level; and

7. more thorough and valid analyses of the short- and long-run consequences of alternative actions for developing employment opportunities for rural workers.

What these requirements for knowledge have in common is their content of social science. The USDA has perhaps a greater capacity for social science research than any other federal agency. Land-grant universities have capacity for research in the applied social sciences. Each is organically linked to the cooperative extension service, with an unusual capacity for disseminating complex information. Taken together, the landgrant system has a long and useful tradition of problem-oriented pro-

\footnotetext{
${ }^{8}$ Ideological militance of the rural areas may have forced smaller metropolitan areas into political alliance with large ones, because rural areas do not recognize the extent of their interdependence with smaller metropolitan and submetropolitan centers.
} 
grams, of interdisciplinary efforts, and of concern for rural welfare. What else is needed but a desire to come to grips with poverty problems?

\section{Literature Cited}

[1] Bachmura, Frank T., Agricultural Unemployment and Underemployment and Government Program Approaches, ERS, USDA, Washington, D.C., March 26-28, 1963.

[2] - Manpower Retraining in the South's Rural Population-An Opportunity for Development, ERS, USDA, Washington, D.C., February 4-6, 1963.

[3] USDA, Balance Sheet of Agriculture, 1962, Agr. Info. Bul. 270, Washington, D.C., 1963.

[4] Bishop, C. E., "Economic Aspects of Migration from Farms in the United States," Labor Mobility and Population in Agriculture, Ames, Iowa State University Press, 1961.

[5] "Employment Projections by Industry and Occupation, 1960-75," Monthly Labor Review, March 1963.

[6] U.S. Department of Commerce, Investing in Jobs, Area Redevelopment Administration, Washington, D.C., 1962.

[7] Johnston, Denis F., "Educational Attainment of Workers, March 1962," Monthly Labor Review, March 1963.

[8] Myers, Robert J. and John H. Chandler, "International Comparisons of Unemployment," Monthly Labor Review, August 1962.

[9] Outdoor Recreation Resources Review Commission, Projections to the Years 1976 and 2000: Economic Growth, Population, Labor Force and Leisure, and Transportation, Study Report 23, Washington, D.C., 1962, Tables E-6 and E-6b.

[10] Rinehart, James R., "Rates of Return on Municipal Subsidies to Industry," Southern Econ. Jour. Vol. 129, pp. 297-306.

[11] Schultz, T. W., "Economic Policy Research for Agriculture," Canadian J. Agr. Econ., Vol. 9, No. 2, pp. 97-106. 